\title{
Front Matter: Volume 11162
}

, "Front Matter: Volume 11162," Proc. SPIE 11162, High Power Lasers: Technology and Systems, Platforms, Effects III, 111620R (26 November 2019); doi: 10.1117/12.2556196

SPIE. Event: SPIE Security + Defence, 2019, Strasbourg, France 


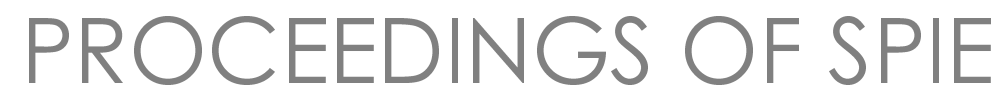

\section{High Power Lasers: Technology and Systems, Platforms, Effects III}

Harro Ackermann

Willy L. Bohn

David H. Titterton

Editors

11-12 September 2019

Strasbourg, France

Sponsored and Published by

SPIE

Cooperating Organisations

European Optical Society

Cranfield University (United Kingdom)

Volume 11162 
The papers in this volume were part of the technical conference cited on the cover and title page. Papers were selected and subject to review by the editors and conference program committee. Some conference presentations may not be available for publication. Additional papers and presentation recordings may be available online in the SPIE Digital Library at SPIEDigitallibrary.org.

The papers reflect the work and thoughts of the authors and are published herein as submitted. The publisher is not responsible for the validity of the information or for any outcomes resulting from reliance thereon.

Please use the following format to cite material from these proceedings:

Author(s), "Title of Paper," in High Power Lasers: Technology and Systems, Platforms, Effects III, edited by Harro Ackermann, Willy L. Bohn, David H. Titterton, Proceedings of SPIE Vol. 11162 (SPIE, Bellingham, WA, 2019) Seven-digit Article CID Number.

ISSN: 0277-786X

ISSN: 1996-756X (electronic)

ISBN: 9781510630277

ISBN: 9781510630284 (electronic)

Published by

SPIE

P.O. Box 10, Bellingham, Washington 98227-0010 USA

Telephone +1 3606763290 (Pacific Time) · Fax +1 3606471445

SPIE.org

Copyright @ 2019, Society of Photo-Optical Instrumentation Engineers.

Copying of material in this book for internal or personal use, or for the internal or personal use of specific clients, beyond the fair use provisions granted by the U.S. Copyright Law is authorized by SPIE subject to payment of copying fees. The Transactional Reporting Service base fee for this volume is $\$ 21.00$ per article (or portion thereof), which should be paid directly to the Copyright Clearance Center (CCC), 222 Rosewood Drive, Danvers, MA 01923. Payment may also be made electronically through CCC Online at copyright.com. Other copying for republication, resale, advertising or promotion, or any form of systematic or multiple reproduction of any material in this book is prohibited except with permission in writing from the publisher. The CCC fee code is $0277-$ $786 \times / 19 / \$ 21.00$.

Printed in the United States of America by Curran Associates, Inc., under license from SPIE.

Publication of record for individual papers is online in the SPIE Digital Library.

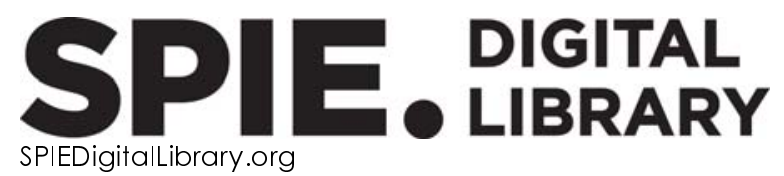

Paper Numbering: Proceedings of SPIE follow an e-First publication model. A unique citation identifier (CID) number is assigned to each article at the time of publication. Utilization of CIDs allows articles to be fully citable as soon as they are published online, and connects the same identifier to all online and print versions of the publication. SPIE uses a seven-digit CID article numbering system structured as follows:

- The first five digits correspond to the SPIE volume number.

- The last two digits indicate publication order within the volume using a Base 36 numbering system employing both numerals and letters. These two-number sets start with 00, 01, 02, 03, 04, 05, 06, 07, 08, 09, 0A, OB ... 0Z, followed by 10-1Z, 20-2Z, etc. The CID Number appears on each page of the manuscript. 


\title{
Contents
}

\author{
$\checkmark \quad$ Authors \\ vii Conference Committee
}

\section{POSTERS SESSION}

$1116201 \quad$ Anti-satellite capability of a chemical oxygen-iodine laser in a high-altitude airship [1 $1162-23]$

$1116202 \quad$ Spatial beam shaping by using small-aperture SLM in a high power laser [11162-24]

1116203 Design of the power supply system integrated with LD pump module [1 $1162-25]$

1116204 The effects of temperature control in the optical parametric oscillator laser system [1 1162-26]

1116205 Research on the LD side pumping field of solid-state lasers [1 $1162-27]$

\section{LASER ARCHITECTURES FOR POWER SCALING AND PLATFORMS}

$1116207 \quad$ High-power laser development for laser weapons (Invited Paper) [1 $1162-2]$

1116209 Characterization of beam quality of 10-kW class laser [1 $11162-4]$

$111620 \mathrm{~A} \quad$ Investigation of the end pump surface gain medium slab laser [11162-5]

DIODE-PUMPED ALKALI LASERS AND OPTICALLY PUMPED RARE GAS LASERS

$11162 \mathrm{OB} \quad$ Measuring and modelling the beam quality in cesium DPALs [11162-7]

11162 OD Hybrid molecular gas laser system operating within wavelength range of 1.7-19.3 micron [1 $11162-9]$ 
FIBER LASERS AND BEAM COMBINING

$111620 \mathrm{G}$ The materials science and engineering of optical nonlinearities and their mitigation in high power lasers (Invited Paper) [11162-11]

LASER INTERACTION, EFFECTS AND COMPONENTS

11162 OL Numerical modelling of laser filamentation (Invited Paper) [1 $1162-17]$

$111620 \mathrm{M} \quad$ Time resolved spectroscopic temperature measurement techniques during CW-laser matter interaction of Glass-Fiber-Reinforced-Polymers (GFRP) [1 $11162-18]$

$1116200 \quad$ Mid-infrared spectroscopy of laser filamentation in optics [1 $1162-20]$

11162 OP Experimental and numerical investigations of laser-induced thermal effects on composite materials [1 $11162-21]$

$111620 Q \quad$ Modelling of the thermal initiation process for encased explosives [1 $1162-22]$ 


\title{
Authors
}

Numbers in the index correspond to the last two digits of the seven-digit citation identifier (CID) article numbering system used in Proceedings of SPIE. The first five digits reflect the volume number. Base 36 numbering is employed for the last two digits and indicates the order of articles within the volume. Numbers start with 00, 01, 02, 03, 04, 05, 06, 07, 08, 09, OA, OB...0Z, followed by 10-1Z, 20-2Z, etc.

\author{
Allheily, V., OM, OP \\ Auslender, llya, $\mathrm{OB}$ \\ Ballato, John, 0G \\ Barmashenko, Boris D., OB \\ Borchert, H., OM \\ Cai, Jun, 02 \\ Cavillon, M., OG \\ Chowdhury, Enam, 00 \\ Cui, Li, 05 \\ Dragic, P. D., OG \\ Ensley, Trenton, 00 \\ Geng, Hongwei, 03 \\ Gontar, Przemysław, 09 \\ Gorajek, Łukasz, 09 \\ Gu, Haidong, 05 \\ $\mathrm{HaO}, \mathrm{He}, \mathrm{O} 5$ \\ Hawkins, T. W., $0 G$ \\ Hu, Wenhua, 03 \\ Huang, Xinru, 03 \\ Ionin, Andrey, OD \\ Jabczyński, Jan K., 09 \\ Jiang, Jinfeng, 03, 05 \\ Jin, Yan, 03 \\ Jung, M., 07 \\ Kinyaevskiy, Igor, OD \\ Klimachev, Yurii, OD \\ Kopczyński, Krzysztof, 09 \\ Kotkov, Andrei, OD \\ Kozlov, Andrei, OD \\ L'Hostis, G., OP \\ Li, Dong, 03 \\ Li, Sensen, 02 \\ Li, Zhuo, 04 \\ Liang, Xingbo, OA \\ Liem, A., 07 \\ Liu, Jiao, OA \\ Liu, Yang, $\mathrm{OA}$ \\ Liu, Yiping, 04 \\ Lu, Zhiwei, 02 \\ Ludewigt, K., 07 \\ Merlat, L., OM, OP \\ Ren, Shilong, 04 \\ Rosenwaks, Salman, OB \\ Sagitova, Adilya, OD \\ Schmitt, Rüdiger, OM, OQ \\ Schweinsberg, Aaron, 00 \\ Seleznev, Leonid, OD \\ Sinitsyn, Dmitry, OD \\ Stuhr, U., 07
}

\author{
Takehisa, K., 01 \\ Talisa, Noah, 00 \\ Tang, Xiaojun, $\mathrm{OA}$ \\ Tripepi, Michael, 00 \\ Valenzuela, Anthony, 00 \\ Vanderhoef, Laura, 00 \\ Wang, Chao, OA \\ Wang, Ke, OA \\ Wang, Wentao OA \\ Wang, Yanxin, 04 \\ Wang, Yulei, 02 \\ Werner, Kevin, 00 \\ Wilmer, Brian, 00 \\ Wolfe, Christopher, 00 \\ Yacoby, Eyal, OB \\ Yan, Xiusheng, 02 \\ Zhang, Yizhuo, 03, 04, 05 \\ Zhao, Hong, 0 A \\ Zhao, Wanli, 02
}


Proc. of SPIE Vol. 11162 111620R-6 Downloaded From: https://www.spiedigitallibrary.org/conference-proceedings-of-spie on 26 Apr 2023
Terms of Use: https://www.spiedigitallibrary.org/terms-of-use 


\title{
Conference Committee
}

\author{
Symposium Chairs
}

Ric Schleijpen, TNO (Netherlands)

Karin U. Stein, Fraunhofer-Institut für Optronik, Systemtechnik und Bildauswertung (Germany)

Symposium Co-chair

Catherine Barrat, HGH Systèmes Infrarouges (France)

Conference Chairs

Harro Ackermann, Joint Directed Energy Transition Office

(United States)

Willy L. Bohn, BohnLaser Consult (Germany)

David H. Titterton, UK Defence Academy (United Kingdom)

Conference Programme Committee

Pierre Bourdon, ONERA (France)

Martin C. Richardson, CREOL, The College of Optics and Photonics, University of Central Florida (United States)

Jasbinder S. Sanghera, U.S. Naval Research Laboratory

(United States)

Session Chairs

1 Laser Architectures for Power Scaling and Platforms

Harro Ackermann, Joint Directed Energy Transition Office

(United States)

2 Diode-pumped Alkali Lasers and Optically Pumped Rare Gas Lasers

Boris D. Barmashenko, Ben-Gurion University of the Negev (Israel)

Willy L. Bohn, BohnLaser Consult (Germany)

3 Fiber Lasers and Beam Combining

Willy L. Bohn, BohnLaser Consult (Germany)

4 Laser Interaction, Effects and Components

Pierre Bourdon, ONERA (France)

David H. Titterton, Cranfield Defence and Security (United Kingdom) 
Proc. of SPIE Vol. 11162 111620R-8

Downloaded From: https://www.spiedigitallibrary.org/conference-proceedings-of-spie on 26 Apr 2023
Terms of Use: https://www.spiedigitallibrary.org/terms-of-use

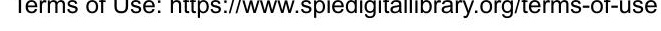

